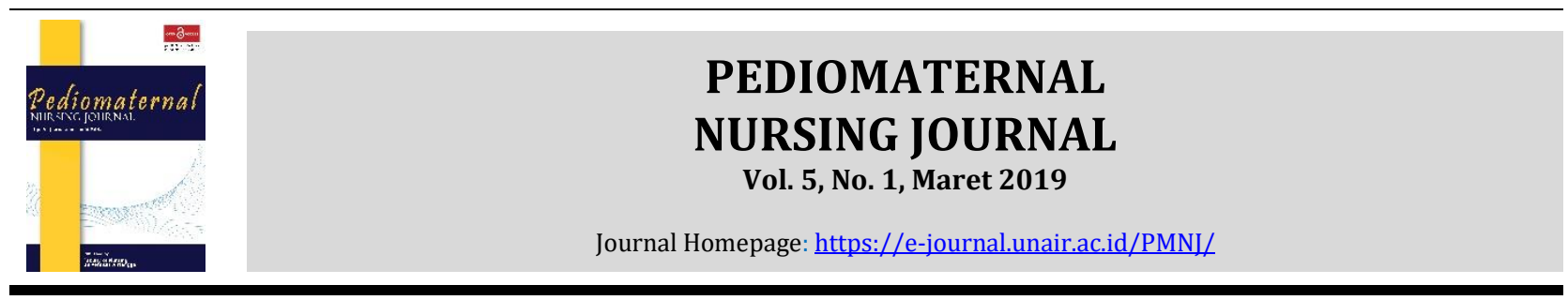

Original Research

\title{
Analisis Faktor yang berhubungan dengan Kualitas Hidup Wanita Penderita Kanker
}

\section{(Analysis of factors related to the quality of life on women with cancer)}

\author{
Naomi Toulasik, Tiyas Kusumaningrum, dan Retnayu Pradanie \\ Fakultas Keperawatan, Universitas Airlangga, Surabaya, Jawa Timur, Indonesia
}

ARTICLE HISTORY
Received: March 17,2019
Accepted: April 11, 2019
KEYWORDS
cancer; women; quality of life;
age; life style
CORRESPONDING AUTHOR
Naomi Toulasik
naomi.toulasik-
2017@fkp.unair.ac.id
Fakultas Keperawatan,
Universitas Airlangga, Surabaya,
Jawa Timur, Indonesia

\begin{abstract}
Introduction: Cancer is a group of diseases characterized by uncontrolled growth and spread of abnormal cells which can cause death. Cancer has a great impact on sufferers both physically, psychologically and socially which will affect their quality of life. There are many factors that affect quality of life.

Methods: This study used cross sectional design. The population of this study were all cancer patients aged $\geq 18$ years in General hospital of Prof. DR. W. Z. Johannes Kupang. The sample size was 103 respondents who met the inclusion criteria. The dependent variable was the quality of life of women with cancer, while the independent variables were age, marital status, lifestyle, body mass index, cancer type and the stage of cancer. Data was collected using questionnaires. Data then analyzed using Ordinal Regression.

Results: There were correlations between age $(p=0.015)$, marital status $(p=0,000)$, cancer types $(p=0.041)$ and stage of cancer $(p=0,000)$ with quality of life. There was no correlation between lifestyle and body mass index with quality of life.

Conclusion: Quality of life of women with cancer are influenced by age, marital status, type of cancer and stage of cancer. Further researchers are advised to examine the relation between psychological, physical environmental, and social environmental factors to the quality of life of women with cancer.
\end{abstract}

Toulasik, N., Kusumaningrum, T., \& Pradanie, R. (2019). Analisis Faktor yang berhubungan dengan Kualitas Hidup Wanita Penderita Kanker. Pediomaternal Nurs. J., 5(1), 9-16.

\section{PENDAHULUAN}

Wanita mempunyai peranan sentral dalam menentukan kualitas keluarga dan kualitas generasi penerus. Peran wanita sebagai istri adalah pendamping, penolong, pelengkap, penghibur, penguat, pendukung, pencinta dan pembimbing rohani suami. Sedangkan peran wanita sebagai seorang ibu adalah merawat dan mengurus keluarga, memenuhi kebutuhan fisiologis dan psikis, sebagai seorang pendidik, pelindung, panutan dan motivator dalam keluarga (1).

Kanker memberikan dampak yang besar bagi penderitanya baik secara fisik, psikologis maupun sosial. Masalah fisik yang dialami penderita kanker adalah nyeri, ketergantungan akan kegiatan seharihari, masalah tidur, kehilangan nafsu makan, mulut kering, kesulitan menelan makanan dan kelelahan (2). Untuk aspek psikologis, pasien mengalami kebingungan, kemurungan, kecemasan, perasaan tidak berdaya, perasaan bersalah dan kesendirian (3). Untuk masalah aspek sosial, pasien kanker dikuasai perasaan tidak berguna, kekhawatiran karenamerasa menjadi beban orang lain dan merasa malu karena tidak mempunyai arti bagi orang lain. Perempuan yang mempunyai perspektif masa depan yang lebih baik memiliki kemungkinan hidup lebih lama dibandingkan dengan wanita yang perspektif masa depannya buruk. Data yang diperoleh pada tahun 2012 oleh (4) terdapat 14,1 juta kasus kanker 
yang didiagnosis di seluruh dunia dan sekitar 8,2 juta kasus kematian akibat kanker. Pada wanita, kanker payudara mendominasi kasus kanker disusul oleh kanker serviks. Berdasarkan estimasi Global Berden Cancer (Globocan), International Agency for Research on Cancer (IARC) tahun 2012 dalam (5), prevalensi penyakit payudara di Indonesia cukup tinggi yaitu 1,4\% dengan insiden kanker sebesar 40 per 100.000 perempuan dan kanker leher rahim 17 per 100.000 perempuan.

Kualitas hidup adalah persepsi individu mengenai posisi mereka dalam kehidupan dalam konteks budaya dan sistem nilai di mana mereka hidup dan dalam kaitannya dengan tujuan, harapan standar, dan perhatian mereka (6). Hidup yang berkualitas merupakan kondisi dimana pasien walaupun mengalami penyakit yang dideritanya, dapat tetap merasa nyaman secara fisik, psikologis, sosial, maupun spiritual serta secara optimal memanfaatkan hidupnya untuk kebahagiaan dirinya maupun orang lain (7). Wanita yang divonis kanker kadang tidak mampu beradaptasi dan menerima kenyataan bahwa dirinya terkena kanker. Kondisi kualitas hidup wanita penderita kanker bervariasi karena setiap individu memiliki strategi koping yang berbeda (8).

Hidup yang berkualitas merupakan tujuan yang ingin dicapai oleh semua manusia pada semua tingkatan umur. Kualitas hidup dipengaruhi oleh karakteristik individu dan karakteristik lingkungan (9). Karakteristik individu terdiri dari faktor demografi, faktor perkembangan, faktor psikologis dan faktor biologis. Sedangkan karakteristik lingkungan terdiri dari faktor lingkungan fisik dan faktor lingkungan sosial. Persepsi yang baik tentang kesehatan seseorang memberi pengaruh pada kualitas hidup seseorang (7). Klien yang mampu beradaptasi dengan kondisinya akan memiliki kemampuan dalam menjalankan peran dan fungsi sebagai wanita dalam kehidupan. Klien dengan penerimaannnya terhadap penyakit akan memiliki kondisi psikologis yang baik sehingga motivasi dan keinginan untuk sembuh semakin tinggi serta kualitas hidup klien dapat meningkat.

\section{METODE}

\subsection{Desain}

Penelitian ini menggunakan desain deskriptif analitik dengan pendekatan cross sectional.

\subsection{Populasi, sampel, dan sampling}

Populasinya adalah semua wanita penderita kanker berusia $\geq 18$ tahun di RSU Prof. DR. W. Z. Johannes Kupang, sebanyak 103 penderita. Teknik pengambilan sampel yang digunakan pada penelitian ini adalah non probability sampling dengan metode purposive sampling yaitu suatu tekhnik penetapan sampel dengan cara memilih sampel diantara populasi sesuai dengan yang dikehendaki peneliti (tujuan/masalah dalam penelitian), sehingga sampel tersebut dapat mewakili karakteristik populasi yang telah dikenal sebelumnya. Kriteria inklusi dalam penelitian ini adalah 1) wanita usia $\geq 18$ tahun, 2) wanita penderita kanker dengan kesadaran komposmentis, 3) Wanita penderita kanker yang bisa membaca dan menulis. Sedangkan kriteria eksklusinya adalah wanita penderita kanker yang mengalami gangguan jiwa.

\subsection{Variabel}

Variabel independen dalam penelitian ini adalah faktor demografi (usia dan status pernikahan, karakteristik individu: faktor perkembangan (gaya hidup) dan karakteristik individu: faktor biologis (IMT, jenis kanker dan stadium kanker). Variabel dependen adalah kualitas hidup wanita penderita kanker.

\subsection{Instrumen}

Kuesioner yang memberikan gambaran mengenai karakteristik individu: usia, status pernikahan dan karakteristik biologis: BB dan TB, jenis kanker dan stadium kanker, dimodifikasi oleh peneliti berdasarkan teori Ferrans model of quality of life. Kuesioner ini menggunakan jenis pertanyaan terbuka.

Kuesioner gaya hidup, diadopsi dari penelitian terdahulu oleh (10) yang meneliti mengenai Determinan perilaku "cerdik" sebagai upaya pencegahan penyakit tidak menular pada masyarakat peserta Posbindu PTM (Studi deskriptif di Puskesmas Gumukmas Kecamatan Gumukmas Kabupaten Jember). Kuesioner ini terdiri dari 29 pertanyaan dengan 4 pilihan jawaban, yaitu: tidak pernah, kadang-kadang, sering dan selalu.

Kuesioner tentang kualitas hidup wanita penderita kanker diadopsi dari Translation and Validation of EORTC QLQ-C30 into Indonesian Version for Cancer Patients in Indonesia oleh (11), yang terdiri dari 30 pertanyaan yang mencakup : 1) Status kesehatan umum, terdiri atas 2 pertanyaan yang termuat dalam nomor 29 dan 30. Berisikan pertanyaan yang mengarah pada pendapat pasien terhadap kualitas kesehatan hidupnya 2) Skala fungsional, yang terdiri dari: Fungsi fisik terdiri dari 5 pertanyaan, termuat dalam nomor $1,2,3,4,5$. Berisikan pertanyaan yang mengarah pada gejala yang dirasakan tubuh seperti kesulitan-kesulitan saat melakukan aktivitas sehari -hari; Fungsi peran terdiri dari 2 pertanyaan, termuat dalam nomor 6 dan 7. Berisikan pertanyaan yang mengarah pada keterbatasan melakukan kegiatan sehari-hari dan ketika melakukan kegiatan yang hanya dilakukan di waktu senggang; Fungsi emosional terdiri dari 4 pertanyaan, termuat dalam nomor 21, 22, 23, 24. Berisikan pertanyaan yang mengarah pada masalah emosional seperti perasaan khawatir, tegang, mudah marah dan depress; Fungsi kognitif terdiri dari 2 pertanyaan, termuat dalam nomor 20 dan 25 . Berisikan pertanyaan yang mengarah pada kesulitan berkonsentrasi dan mengingat; Fungsi sosial terdiri dari 2 pertanyaan termuat dalam nomor 26 dan 27 . Berisikan pertanyaan yang mengarah pada kehidupan dalam keluarga dan aktivitas sosial. 3) 
Skala gejala terdiri dari 13 pertanyaan, termuat dalam nomor $8,9,10,11,12,13,14,15,16,17,18,19$ dan 28. Berisikan pertanyaan yang mengarah pada keluhan kesehatan seperti bernafas, nyeri dan mualmual.

\subsection{Prosedur}

Peneliti mengidentifikasi (menyeleksi) responden sesuai dengan kriteria inklusi di 2 ruangan perawatan pasien dengan kanker yaitu ruang rawat inap (Mutis) dan Poli kemotherapy. Memberikan penjelasan tentang tujuan dan prosedur penelitian. Pasien yang bersedia menjadi responden, diberikan informed consent untuk ditandatangani.

Peneliti memberikan kuesioner mengenai karakteristik individu, kuesioner gaya hidup dan kuesioner kualitas hidup kepada responden. Terdapat perbedaan pengumpulan data di ruang Mutis dan ruang kemotherapy. Selama proses pengisian lembar kuesioner di ruangan rawat inap (Mutis), peneliti langsung mendampingi responden di sisi tempat tidurnya, sehingga apabila responden tidak mengerti dengan maksut pertanyaan, peneliti menjelaskan kepada responden agar mendapatkan data yang valid. Sedangkan di ruang poli kemotherapy, responden diobservasi secara berkelompok.

Setelah kuesioner selesai diisi oleh responden, peneliti melakukan pengecekan terhadap pengisian kuesioner untuk memastikan bahwa kuesioner telah diisi lengkap oleh responden. Setelah data terkumpul maka proses selanjutnya adalah proses pengolahan data.

\subsection{Analisis}

Penelitian ini dilakukan analisis dengan IBM SPSS Statistic 21 dengan uji regresi logistik ordinal dengan tingkat signifikansi $\alpha \leq 0,05$.

\subsection{Ethical Clearance}

Penelitian ini telah lulus uji etik oleh Komite Etik Fakultas Keperawatan dengan nomor sertifikat etik No 1231-KEPK yang dikeluarkan oleh Komite Etik Penelitian Kesehatan Fakultas Keperawatan Universitas Airlangga pada tanggal 19 Desember 2018.

\section{Hasil}

Usia terbanyak pada wanita penderita kanker di RSU Prof. DR. W. Z. Johannes Kupang yaitu pada kategori lansia sebanyak 58 orang $(56,3 \%)$ sedangkan paling sedikit adalah manula dan remaja, masing-masing sebanyak 2 orang $(1,9 \%)$. Status pernikahan terbanyak pada wanita penderita kanker di RSU Prof. DR. W. Z. Johannes Kupang adalah menikah sebanyak 70 orang $(67,9 \%)$ sedangkan yang paling sedikit adalah cerai sebanyak 2 orang $(1,9 \%)$.

Jumlah wanita penderita kanker sebanyak 43 orang $(41,7 \%)$ dengan gaya hidup baik mempunyai kualitas hidup sedang. Namun terdapat 1 orang $(0,9 \%)$ dengan gaya hidup kurang mempunyai kualitas hidup sedang. Berdasarkan hasil analisis statistik dengan regresi ordinal didapatkan nilai Sig. ( $p=0,785$ ) yang berarti faktor perkembangan (gaya hidup) tidak berpengaruh signifikan dengan kualitas hidup wanita penderita kanker di RSUD Prof. DR. W. Z. Johannes Kupang.

Terdapat wanita penderita kanker sebanyak 49 orang $(47,5 \%)$ dengan IMT normal memiliki kualitas hidup sedang. Namun terdapat 3 orang $(2,9 \%)$ dengan IMT kurus juga memiliki kualitas hidup sedang. Hasil analisis statistik dengan regresi ordinal didapatkan nilai Sig. ( $p=0,228$ ) yang berarti IMT tidak berpengaruh signifikan dengan kualitas hidup wanita penderita kanker di RSUD Prof. DR. W. Z. Johannes Kupang. Berdasarkan jenis kanker, terdapat 27 orang $(26,2 \%)$ penderita kanker payudara memiliki kualitas hidup sedang. Namun terdapat 1 orang $(0,9 \%)$ penderita kanker colon yang juga memiliki kualitas hidup sedang. Hasil analisis statistik dengan regresi ordinal didapatkan nilai Sig. ( $p=$ 0,041) yang berarti jenis kanker berpengaruh signifikan dengan kualitas hidup wanita penderita kanker di RSUD Prof. DR. W. Z. Johannes Kupang. Berdasarkan stadium kanker, terdapat 36 orang (34,9\%) penderita kanker stadium II (sedang) memiliki kualitas hidup sedang. Namun terdapat 1 orang $(0,9 \%)$ penderita kanker stadium I (ringan) yang memiliki kalitas hidup sedang. Hasil analisis statistik dengan regresi ordinal didapatkan nilai Sig. $(p=0,000)$ yang berarti stadium kanker berpengaruh signifikan dengan kualitas hidup wanita penderita kanker di RSUD Prof. DR. W. Z. Johannes Kupang. [Tabel 1].

\section{PEMBAHASAN}

\subsection{Faktor demografi: usia dan status pernikahan}

Faktor usia berpengaruh secara signifikan dengan kualitas hidup wanita penderita kanker di RSUD Prof. DR. W. Z. Johannes Kupang. Hasil penelitian ini juga sejalan dengan hasil penelitian (12) yaitu mereka yang berusia lansia memiliki masalah dengan mobilitas, perawatan diri dan kegiatan sehari-hari 3,42 kali lebih tinggi dibandingkan mereka yang berusia remaja atau dewasa.

Kualitas hidup adalah perasaan sejahtera individu, yang berasal dari rasa puas atau tidak puas individu dengan area kehidupan yang penting baginya (9). Faktor demografi (usia) merupakan salah satu faktor yang berpengaruh terhadap kualitas hidup. Pasien dengan kategori lansia (di atas 45 tahun) mempunyai kualitas hidup lebih rendah karena dengan bertambahnya usia akan terjadi perubahan pada fungsi dan anatomi tubuh sehingga mereka akan mengalami keterbatasan dalam melakukan aktivitas yang pada akhirnya berpengaruh pada kualitas hidup mereka. Proses menua yaitu proses yang mengubah seorang dewasa berbagai penyakit kronis (13). Hal ini dapat terjadi karena berkurangnya sebagian besar sehat menjadi 
Tabel 1. Hubungan Faktor Demografi, Faktor Perkembangan dan Faktor Biologis dengan Kualitas Hidup Wanita Penderita Kanker di RSUD Prof. DR. W. Z. Johannes Kupang Desember 2018

\begin{tabular}{|c|c|c|c|c|c|c|c|c|c|c|c|}
\hline \multirow[t]{2}{*}{ No } & \multirow{2}{*}{\multicolumn{2}{|c|}{ Variabel }} & \multicolumn{2}{|c|}{ Buruk } & \multicolumn{2}{|c|}{$\begin{array}{l}\text { Kualitas hidup } \\
\text { Sedang }\end{array}$} & \multicolumn{2}{|c|}{ Baik } & \multicolumn{2}{|c|}{ Total } & \multirow[t]{2}{*}{$\operatorname{Sig}(p)$} \\
\hline & & & $\mathbf{f}$ & $\%$ & $\mathbf{f}$ & $\%$ & f & $\%$ & f & $\%$ & \\
\hline 1. & $\begin{array}{l}\text { Demografi: } \\
\text { Usia }\end{array}$ & $\begin{array}{l}18-25 \\
\text { tahun }\end{array}$ & 0 & 0 & 1 & 0,9 & 1 & 0,9 & 2 & 1,9 & \multirow{5}{*}{0,015} \\
\hline & & $\begin{array}{l}26-45 \\
\text { tahun }\end{array}$ & 6 & 5,8 & 32 & 30 & 3 & 2,9 & 41 & 39,8 & \\
\hline & & $\begin{array}{l}46-65 \\
\text { tahun }\end{array}$ & 22 & 21,3 & 35 & 33,9 & 1 & 0,9 & 58 & 56,3 & \\
\hline & & $\begin{array}{l}>65 \\
\text { tahun }\end{array}$ & 2 & 1,9 & 0 & 0 & 0 & 0 & 2 & 1,9 & \\
\hline & & Total & 30 & 29,1 & 68 & 66 & 5 & 4,8 & 103 & 100 & \\
\hline & \multirow[t]{6}{*}{$\begin{array}{l}\text { Status } \\
\text { pernikahan }\end{array}$} & Lajang & 3 & 2,9 & 13 & 12,6 & 1 & 0,9 & 17 & 16,5 & \multirow{6}{*}{0,000} \\
\hline & & Menikah & 12 & 11,6 & 54 & 52,4 & 4 & 3,9 & 70 & 67,9 & \\
\hline & & Cerai & 2 & 1,9 & 0 & 0 & 0 & 0 & 2 & 1,9 & \\
\hline & & Janda & 9 & 8,7 & 1 & 0,9 & 0 & 0 & 10 & 9,7 & \\
\hline & & $\begin{array}{l}\text { Hidup } \\
\text { bersama }\end{array}$ & 4 & 3,9 & 0 & 0 & 0 & 0 & 4 & 3,9 & \\
\hline & & Total & 30 & 29,1 & 68 & 66 & 5 & 4,8 & 103 & 100 & \\
\hline \multirow[t]{4}{*}{2.} & \multirow[t]{4}{*}{$\begin{array}{l}\text { Perkembangan : } \\
\text { Gaya hidup }\end{array}$} & Kurang & 4 & 3,9 & 1 & 0,9 & 1 & 0,9 & 6 & 5,8 & \multirow{4}{*}{0,785} \\
\hline & & Cukup & 7 & 6,8 & 24 & 23,3 & 2 & 1,9 & 33 & 32 & \\
\hline & & Baik & 19 & 18,4 & 43 & 41,7 & 2 & 1,9 & 64 & 62,1 & \\
\hline & & Total & 30 & 29,1 & 68 & 66 & 5 & 4,8 & 103 & 100 & \\
\hline \multirow[t]{16}{*}{3.} & \multicolumn{10}{|l|}{ Biologis: } & \multirow{5}{*}{0,228} \\
\hline & \multirow[t]{4}{*}{ IMT } & Kurus & 1 & 0,9 & 3 & 2,9 & 1 & 0,9 & 5 & 4,8 & \\
\hline & & Normal & 22 & 21,3 & 49 & 47,5 & 4 & 3,9 & 75 & 72,8 & \\
\hline & & Gemuk & 7 & 6,8 & 16 & 15,5 & 0 & 0 & 23 & 22,3 & \\
\hline & & Total & 30 & 29,1 & 68 & 66 & 5 & 4,8 & 103 & 100 & \\
\hline & \multirow[t]{7}{*}{ Jenis Kanker } & Payudara & 22 & 21,3 & 27 & 26,2 & 0 & 0 & 49 & 47,5 & \multirow{7}{*}{0,041} \\
\hline & & Serviks & 2 & 1,9 & 15 & 14,5 & 0 & 0 & 17 & 16,5 & \\
\hline & & Ovarium & 2 & 1,9 & 16 & 15,5 & 0 & 0 & 18 & 17,5 & \\
\hline & & Colon & 0 & 0 & 1 & 0,9 & 0 & 0 & 1 & 0,9 & \\
\hline & & Paru & 0 & 0 & 2 & 1,9 & 1 & 0,9 & 3 & 2,9 & \\
\hline & & Lainnya & 4 & 3,9 & 7 & 6,8 & 4 & 3,9 & 15 & 14,5 & \\
\hline & & Total & 30 & 29,1 & 68 & 66 & 5 & 4,8 & 103 & 100 & \\
\hline & \multirow[t]{4}{*}{ Stadium Kanker } & $\begin{array}{l}\text { I } \\
\text { (Ringan) }\end{array}$ & 0 & 0 & 1 & 0,9 & 4 & 3,9 & 5 & 4,8 & \multirow{4}{*}{0,000} \\
\hline & & II & 5 & 4,8 & 36 & 34,9 & 0 & 0 & 41 & 39,8 & \\
\hline & & $\begin{array}{l}\text { III - IV } \\
\text { (Berat) }\end{array}$ & 25 & 24,2 & 31 & 30 & 1 & 0,9 & 57 & 55,3 & \\
\hline & & Total & 30 & 29,1 & 68 & 66 & 5 & 4,8 & 103 & 100 & \\
\hline
\end{tabular}

seorang yang rentan (frail) akan cadangan sistem fisiologis dan meningkatnya kerentanan terhadap berbagai penyakit dan kematian. Namun kualitas hidup yang buruk tidak hanya dialami oleh wanita penderita kanker berusia lansia saja tetapi juga terdapat sebagian kecil responden berusia dewasa yang memiliki kualitas hidup buruk. Responden dengan usia yang lebih muda dan mempunyai keterbatasan fisik juga akan mempengaruhi fungsi emosional mereka. Karena adanya keterbatasan fisik menyebabkan mereka tidak dapat mengerjakan tugas-tugas perkembangan mereka secara total.

Tugas-tugas perkembangan pada masa dewasa awal mencakup mulai bekerja, memilih pasangan hidup, mulai membina keluarga, mengasuh anak, mengelola rumah tangga, mengambil tanggung jawab sebagai warga negara dan mencari kelompok sosial yang menyenangkan (14). Perubahan fisik seperti penurunan berat badan dan kehilangan rambut juga menyebabkan individu merasa berbeda sehingga mempengaruhi self-esteem mereka. Penurunan fungsi fisik selama kemoterapi dapat terjadi karena perempuan yang lebih muda cenderung memiliki harapan yang lebih tinggi terhadap kesehatan mereka, sehingga lebih sulit dalam mengatasi penyakitnya dan pada akhirnya mereka memiliki kualitas hidup yang buruk (14).

Sebagian besar responden $(52,4 \%)$ dengan status menikah memiliki kualitas hidup sedang. Namun terdapat sebagian kecil responden $(11,6 \%)$ dengan status menikah juga memiliki kualitas hidup buruk. Status pernikahan signifikan berhubungan dengan 
kualitas hidup wanita penderita kanker di RSUD Prof. DR. W. Z. Johannes Kupang. Penelitian yang sama dilakukan oleh (15) menunjukkan bahwa status pernikahan memiliki hubungan yang sangat signifikan terhadap kualitas hidup pasien dan survivor kanker.

Penelitian lainnya yang dilakukan oleh (16), menunjukkan bahwa pasangan yang menikah memiliki kualitas hidup yang baik, apabila dibandingkan dengan pasangan/individu yang bercerai. Meskipun penelitian ini tidak spesifik dilakukan pada penderita atau survivor kanker, melainkan dilakukan pada individu yang bertempat tinggal di daerah perbatasan, namun dapat pula dijadikan sebagai bahan perbandingkan, karena kedua kelompok individu yang diteliti sama-sama memiliki beban permasalahan baik secara fisik maupun psikis. Faktor demografi (status pernikahan) mempunyai pengaruh terhadap kualitas hidup (9).

Hal ini didukung pula oleh (17) menyatakan bahwa keluarga inti berfungsi untuk mempertahankan lingkungan yang aman baik secara emosional maupun fisik, mengenali dan mengurangi pengaruh dari kejadian-kejadian yang meningkatkan stress (termasuk diagnosis kanker), serta menumbuhkan, mengasuh dan memberi dorongan terhadap perkembangan setiap anggota keluarga. Dukungan yang diperoleh seseorang akan mempercepat pemulihan sakit, meningkatkan kekebalan tubuh, dapat menurunkan stres dan gangguan psikologis (18).

Hal ini berarti bahwa sebagai bagian dari keluarga inti, pasangan memiliki peran yang vital sebagai support system bagi pasien yang menderita kanker/survivor kanker. Kualitas hidup yang buruk juga dialami oleh sebagian kecil responden wanita penderita kanker dengan status menikah. Hal ini disebabkan karena menurunnya fungsi fisik, yaitu responden mengalami kesulitan saat melakukan aktivitas sehari-hari maupun kegiatan yang dilakukan di waktu senggang. Selain itu, responden juga mengalami berbagai masalah kesehatan akibat efek samping dari pengobatan yang dijalani sehingga dirinya menjadi khawatir terhadap kehidupan keluarganya dan sebagai akibatnya kualitas hidupnya menurun.

\subsection{Faktor perkembangan (gaya hidup) dengan kualitas hidup wanita penderita kanker}

Gaya hidup tidak signifikan berhubungan dengan kualitas hidup wanita penderita kanker di RSUD Prof. DR. W. Z. Johannes Kupang. Teori (9) menyatakan bahwa gaya hidup mempunyai pengaruh terhadap kualitas hidup, seperti pada pilihan untuk melakukan latihan fisik yang akan meningkatkan kebugaran fisik pasien, maka akan berpengaruh baik terhadap peningkatan kualitas hidup pasien. Gaya hidup baik (sehat) adalah segala upaya untuk menerapkan kebiasaan yang baik dalam menciptakan hidup yang sehat dan menghindari kebiasaan yang buruk yang dapat mengganggu kesehatan.
Indikator gaya hidup sehat antara lain: pemeriksaan kesehatan rutin, menghindari rokok/asap rokok, rajin aktivitas fisik/olahraga, diet seimbang, istirahat cukup dan kelola stress. Kualitas latihan fisik dan diet yang baik berhubungan dengan kualitas hidup fisik yang lebih baik. Hasil penelitian yang dilakukan oleh (19) yang menganalisis data cross sectional terhadap 1371 survivors menyebutkan bahwa aktivitas fisik hanya berhubungan dengan kualitas hidup dalam domain fisik, tetapi tidak berhubungan dengan kualitas hidup secara mental. Beberapa penghalang yang membatasi penderita kanker melakukan latihan fisik, beberapa diantaranya berhubungan dengan terapi kanker yang sebelumnya telah diperoleh oleh pasien (20).

Misalnya, semua bentuk terapi kanker paru menyebabkan kerusakan fungsi fisik atau fungsional yang bervariasi yang dapat secara dramatis mengurangi toleransi pasien dalam melakukan latihan fisik. Hasil penelitian yang dilakukan pada wanita penderita kanker di RSUD Prof. DR. W. Z. Johannes Kupang menunjukkan bahwa gaya hidup tidak berhubungan signifikan dengan kualitas hidup. Responden dengan gaya hidup baik nyatanya juga dapat memiliki kualitas hidup yang buruk.

Hal ini disebabkan karena mereka sudah menderita kanker dengan kategori stadium berat, sehingga mempunyai pengaruh yang besar terhadap semua aspek dalam kualitas hidup, yaitu aspek fisik, peran, emosional, kognitif, sosial dan skala gejala, yang akhirnya mempengaruhi persepsi responden tentang status kesehatannya. Sedangkan 1 orang responden dengan gaya hidup kurang dapat memiliki kualitas hidup yang baik. Hal ini disebabkan karena responden menderita kanker dengan kategori stadium ringan sehingga belum terlalu banyak permasalahan fisik yang dihadapi. Selain itu responden mengatakan bahwa ia selalu mendapatkan dukungan dari anggota keluarganya dan ia yakin dapat sembuh dari penyakitnya.

\subsection{Faktor biologis: IMT, jenis kanker dan stadium kanker dengan kualitas hidup wanita penderita kanker}

Terdapat 6,8\% responden dengan IMT gemuk memiliki kualitas hidup buruk dan $(0,9 \%)$ responden dengan IMT kurus memiliki kualitas hidup baik. Teori (9) menyatakan bahwa IMT mempunyai pengaruh terhadap kualitas hidup. Hal ini didukung oleh penelitian yang dilakukan oleh (21), mengemukakan bahwa index massa tubuh (IMT) berhubungan dengan kualitas hidup pasien. Penelitian lain yang sejalan dengan teori Ferrans ini dilakukan oleh (22).

Penelitian yang mereka lakukan terhadap 45 orang pasien kanker kepala dan leher di RSUD Syaiful Anwar Malang, ditemukan bahwa pada analisis multivariat, IMT berhubungan signifikan dengan kualitas hidup pasien kanker kepala dan leher. Pasien dengan kanker payudara, prostat, kolorektal, rahim, dan kulit yang memiliki IMT normal atau lebih 
(overweight) memiliki kualitas hidup yang lebih baik dibanding dengan yang menderita obesitas.

Hasil penelitian yang dilakukan pada wanita penderita kanker di RSUD Prof. DR. W. Z. Johannes Kupang menunjukkan bahwa IMT tidak berhubungan signifikan dengan kualitas hidup. Responden dengan IMT normal dapat memiliki fungsi fisik, sosial dan peran yang baik. Namun, tidak demikian dengan fungsi emosional dan kognitifnya. Mereka juga tetap merasa tegang, khawatir, mudah tersinggung, depresi dan sulit berkonsentrasi yang pada akhirnya menurunkan kualitas hidup mereka.

Terdapat 21,3\% responden dengan jenis kanker payudara memiliki kualitas hidup buruk. Sedangkan $3,9 \%$ responden dengan jenis kanker yang lain (limfoma, Thymoma, recti, parotis, neuroendokrin) memiliki kualitas hidup baik. Hasil penelitian menunjukkan bahwa jenis kanker signifikan berhubungan dengan kualitas hidup wanita penderita kanker di RSUD Prof. DR. W. Z. Johannes Kupang. Hal ini sejalan dengan teori (9) yang menyatakan bahwa jenis kanker mempunyai pengaruh terhadap kualitas hidup.

Responden dengan jenis kanker payudara memiliki kualitas hidup yang paling buruk. Jenis kanker ini menimbulkan dampak psikologis yang besar bagi individu penderitanya karena adanya resiko dilakukan operasi pengangkatan payudara penderita. Kehilangan salah satu anggota badan tubuh karena proses penyembuhan kanker merupakan pengalaman yang traumatik dan memalukan, karena bagi wanita payudara berfungsi sebagai simbol kewanitaan, keindahan dan merupakan organ seksual sekunder sehingga penyakit kanker dapat menghancurkan masa depannya (23).

Hal ini juga diperkuat oleh penelitian yang dilakukan oleh (24) yang menyatakan bahwa ketika seseorang didiagnosa menderita kanker payudara, maka ia akan dihadapkan pada serangkaian pengobatan. Pengobatan atau treatment yang dialami oleh penderita kanker payudara menimbulkan efek tidak menguntungkan baik secara fisik, psikologis, maupun sosial. Secara umum pengobatan dibedakan menjadi surgical (operasi) dan pengobatan systemic (kemoterapi, radioterapi). Operasi yang dilakukan akan meninggalkan bekas luka yang besar di bagian dada, mati rasa, kesulitan dalam melakukan aktivitas sehari-hari, dan perasaan tidak nyaman setelah operasi. Perempuan akan memperhatikan tubuh mereka, luka mereka, cara berpakaian, dan sebagainya. Body image yang rendah secara kuat diasosiasikan dengan distress psikologis dan rendahnya kualitas hidup pada survivor kanker payudara (24).

Terdapat $24,2 \%$ responden dengan stadium kanker III-IV (berat) memiliki kualitas hidup buruk. Namun, terdapat juga $0,9 \%$ responden dengan stadium kanker yang sama, memiliki kualitas hidup baik. Hasil penelitian menunjukkan bahwa stadium kanker signifikan berhubungan dengan kualitas hidup wanita penderita kanker di RSUD Prof. DR. W.
Z. Johannes Kupang. Hal ini sejalan dengan teori (9), yang menyatakan bahwa stadium kanker mempunyai pengaruh terhadap kualitas hidup. Hal ini juga sejalan dengan hasil penelitian dari (25) dalam (26) yang mengemukakan bahwa stadium kanker memiliki hubungan yang signifikan dengan status kesehatan pasien secara global atau keseluruhan kualitas hidup pasien. Pasien dengan kanker stadium I, II, dan III memiliki kualitas hidup yang lebih tinggi dibandingkan dengan pasien kanker stadium IV.

Studi yang dilakukan oleh (27) dalam (26) juga menyebutkan hasil yang sama, yaitu stadium kanker memiliki hubungan langsung terhadap kualitas hidup pasien. Penderita kanker pada stadium lanjut akan memiliki permasalahan fisik yang lebih berat dibandingkan dengan penderita kanker stadium awal karena sel kanker telah menyerang organ-organ lain di dalam tubuh atau yang disebut dengan metastasis. Selain itu, pengobatan terhadap penderita stadium kanker lanjut dapat menyebabkan efek samping termasuk mual dan kelelahan. Permasalahan tersebut kemudian dapat mempengaruhi aspek psikologis pasien sehingga menyebabkan kualitas hidup pasien menurun.

Pada penelitian ini, terdapat juga penderita kanker dengan kategori stadium awal yang memiliki kualitas hidup buruk. Hal ini dapat disebabkan karena responden pada penelitian ini memiliki jenis kanker yang bervariasi. Perbedaan jenis kanker akan berpengaruh terhadap faktor biologis pasien. Penderita kanker paru cenderung memiliki kapasitas paru yang lebih rendah dibanding dengan penderita kanker jenis lainnya meskipun pada stadium yang sama. Selain karena faktor biologis, hal ini dapat pula dipengaruhi oleh faktor lainnya seperti faktor lingkungan, baik lingkungan sosial maupun lingkungan fisik. Lingkungan sosial yang kondusif seperti suport dari keluarga, teman atau pemberi layanan kesehatan, akan memberi pengaruh positif terhadap persepsi pasien dalam proses penerimaan diri serta responnya dalam menjalani pengobatan. Respon yang positif dari pasien akan menghasilkan persepsi kesehatan secara umum yang baik, sehingga akan meningkatkan kualitas hidup pasien (9).

\section{KESIMPULAN}

Karakteristik individu demografi, yaitu usia dan status pernikahan berhubungan dengan kualitas hidup wanita penderita kanker. Pasien dengan kategori lansia (di atas 45 tahun) mempunyai kualitas hidup lebih rendah karena dengan bertambahnya usia akan terjadi perubahan pada fungsi dan anatomi tubuh sehingga mereka akan mengalami keterbatasan dalam melakukan aktivitas yang pada akhirnya berpengaruh pada kualitas hidup mereka. Status pernikahan memiliki peran yang vital sebagai support system bagi pasien yang menderita kanker/survivor kanker sehingga akan mempercepat pemulihan sakit, meningkatkan kekebalan tubuh, menurunkan stres dan gangguan psikologis. 
Karakteristik individu: faktor perkembangan (gaya hidup) tidak berhubungan dengan kualitas hidup wanita penderita kanker. Hal ini disebabkan karena pasien sudah menderita kanker dengan kategori stadium berat sehingga dapat berhubungan dengan semua aspek kualitas hidup wanita penderita kanker.

Karakteristik individu: biologis: IMT tidak berhubungan dengan kualitas hidup wanita penderita kanker karena index masa tubuh tidak berhubungan pada semua aspek dalam kualitas hidup yaitu aspek fungsi emosional dan kognitif. Sedangkan jenis kanker dan stadium kanker berhubungan dengan kualitas hidup wanita penderita kanker. Pengobatan atau treatment yang dialami oleh penderita kanker payudara menimbulkan efek tidak menguntungkan baik secara fisik, psikologis, maupun sosial dan penderita kanker pada stadium lanjut umumnya memiliki gejala-gejala atau keluhan fisik yang lebih berat dibandingkan dengan penderita kanker stadium awal. Gejala-gejala fisik yang semakin berat seiring dengan meningkatnya stadium kanker dengan sendirinya akan membatasi pasien dalam memenuhi kebutuhan dasar serta melaksanakan aktivitas hariannya.

\section{UCAPAN TERIMA KASIH}

Kami mengucapkan terimakasih kepada Direktur Rumah Sakit Umum Daerah Prof. DR. W. Z. Johannes Kupang untuk izin dan penerimaan kami untuk mengambil data sebagai bahan penelitian dan semua wanita penderita kanker yang telah bersedia menjadi responden.

\section{DAFTAR PUSTAKA}

1. Gunarsa PDSD, Gunarsa DNYSD. Psikologi Praktis Anak, Remaja dan Keluarga. 8th ed. Jakarta: BPK Gunung Mulia; 2008.

2. Overcash J, Tan A, Patel K, Noonan AM. Factors Associated With Poor Sleep in Older Women Diagnosed With Breast Cancer. Oncol Nurs Forum. 2018;45(3):359-71.

3. Dewi PF, Kahija YF La. PENGALAMAN MENDERITA KANKER PAYUDARA SEBUAH INTERPRETATIVE PHENOMENOLOGICAL ANALYSIS. scholar. 2018;7(Nomor 1):202-14.

4. Siegel R, Naishadham D, Jemal A. Cancer Statistics , 2013. A Cancer J Clin. 2013;63(1):11-30.

5. Kementerian KRI. Pusat Data dan Informasi Kementerian Kesehatan RI Situasi Penyakit Kanker. Jakarta Kementeri Kesehat Indones. 2015;

6. Nursalam. Metodologi Penelitian Ilmu Keperawatan, Pendekatan Praktis. 4th ed. Lestasi PP, editor. Surabaya: Salemba Medika; 2014.

7. Suhardin S, Kusnanto, Ilya K. ACCEPTANCE
AND COMMITMENT THERAPY ( ACT ) MENINGKATKAN KUALITAS HIDUP PASIEN KANKER ( Acceptance and Commitment Therapy Improve the Quality of Life Patients Suffering Cancer ). J Ners. 2016;11.

8. Towsley GL, Beck SL, Watkins JF. “ Learning to live with it ": Coping with the transition to cancer survivorship in older adults. ScienceDirect. 2007;21:93-106.

9. Ferrans CE, Zerwic JJ, Wilbur JE, Larson JL. Conceptual Model of Health-Related Quality of Life. J Nurs Scholarsh. 2005;

10. Adriana Y. Determinan Perilaku "Cerdik" Sebagai Upaya Pencegahan Penyakit Tidak Menular Pada Masyarakat Peserta Posbindu PTM (Studi Deskriptif di Puskesmas Gumukmas Kecamatan Gumukmas Kabupaten Jember). Jember; 2017.

11. Perwitasari DA, Atthobari J, Dwiprahasto I. Translation and Validation of EORTC QLQ-C30 into Indonesian Version for Cancer Patients in Indonesia Translation and Validation of EORTC QLQ-C30 into Indonesian Version for Cancer Patients in Indonesia. 2011; (June 2014).

12. Xue C, Bian L, Xie YS, Yin ZF, Xu ZJ, Chen QZ, et al. Impact of smoking on health-related quality of Life after percutaneous coronary intervention treated with drug-eluting stents: a longitudinal observational study. Health Qual Life Outcomes [Internet]. 2017 Jan;15(1):1. Available from: https://doi.org/10.1186/s12955-016-05784

13. Sudoyo AW. Buku Ajar Ilmu Penyakit Dalam. Jakarta: Interna Publishing; 2009.

14. Hurlock EB. Psikologi Perkembangan: suatu pendekatan sepanjang rentang kehidupan. 5th ed. Jakarta: Erlangga; 1999.

15. Viebahn-Hänsler R. The use of ozone in medicine: Mechanisms of action. 2015.

16. Gutiérrez M, Oscar V, Esparza A, Villar D. The Possible Protective Effect of Marital Status in Quality of Life Among Elders in a U. S . -Mexico Border City. Community Ment Health J. 2018;54(4):480-4.

17. Potter \& Perry. Fundamental Keperawatan. 2nd ed. Jakarta: EGC; 2006.

18. Taylor, C. R., Lillis, C., LeMone P. Fundamental of nursing. 5th ed. Philadelphia: Lippincott Williams \& Wilkins; 2005.

19. Buffart, Laurien.M.; Thong. Melissa S.Y.; Schep, Goof; Chinapaw,Mai J.M.; Brug,Johannes; Franse LV van de P. Self reported physical activity : it's correlates and relationship with 
N. TOULASIK ET AL.

health-related quality of life in a large cohort of colorectal cancer survivors. PLoS One. 2012;7(5).

20. Vijayvergia, Namrata \& Denlinger CS. LIfestyle factors in cancer survivorship : where we are and where we are headed. J Pers Med. 2015;5:243-63.

21. Mosher CE, Sloane R, Morey MC. Associations Between Lifestyle Factors and Quality of Life Among Older Long-Term Breast, Prostate , and Colorectal Cancer Survivors. 2009;

22. Kurniasari, Fuadiyah Nila; Surono, Agus; \& Pangastuti R. Status gizi sebagai prediktor kualitas hidup pasien kanker kepala dan leher. Indones J Hum Nutr. 2015;2(1):62-7.

23. Lehmann V, Grönqvist $H$, Engvall G, Ander $M$, Tuinman MA, Hagedoorn M, et al. Negative and positive consequences of adolescent cancer 10 years after diagnosis : an interviewbased longitudinal study in Sweden.
2014;1235(April):1229-35.

24. Dahl CAF, Reinertsen K V, Nesvold I. A Study of Body Image in Long-Term Breast Cancer Survivors. Wiley Inter-Science. 2010;354957.

25. Farooqi M, Hassali MA, Knight A et al. Cross Sectional Assessment of Health Related Quality of Life (HRQoL) among patients with cancer in Malaysia. Asian Pacific J Cancer Prev. 2013;14:3017-21.

26. Azmawati MN, Najibah E, Dali M, Zailani A, Norfazilah A. Quality of Life by Stage of Cervical Cancer among Malaysian Patients Quality of Life by Stage of Cervical Cancer among Malaysian Patients. Asian Pacific J Cancer Prev. 2014;15(June):5283-6.

27. Park SY, Bae DS, Nam JH et al. Quality of life and sexual problems in disease-free survivors of cervical cancer compared with the general population. Cancer. 2007;110:2716-25. 